\title{
パラジウムめっき皮膜の水素分析 Analysis of Hydrogen in Palladium Electroplating Films
}

\author{
○学生員 倉田悠生(福井工大・院)フェロー 羽木秀樹(福井工大)
}

Yuuki KURATA, Graduate Student, Fukui University of Technology, 6-1, Gakuen 3-chome, Fukui-shi, Fukui, 910-8505 Hideki HAGI, Fukui University of Technology, 6-1, Gakuen 3-chome, Fukui-shi, Fukui, 910-8505

Key Words. Palladium, Hydrogen Analysis, Electroplating, Hydrogen Embrittlement, Thermal Spectrum of Hydrogen Desorption

\section{1. 緒 言}

パラジウムは、金属アレルギーを起こし難いとされている白色系 貴金属の中で良好な色調を有し、比較的安価であることから、パラ ジウムめつきは装飾用めっきとして利用されている。しかし、これ までのパラジウムめっき処理の方法では、めっき処理工程で多量の 水素がめっき膜に水素が侵入し、水素脆性によるクラックが生じる などの機械的性質の低下が起こりやすく、電着応力も大きいことか ら、小さな応力の負荷によって皮膜の割れや剥離が起こり、厚めつ きは不可能とされている。

パラジウムは貴な金属であるが、電気めっき処理際には金属イオ ンの析出反応に加えて水素イオンの放電反応も起こる。このために、 めつき皮膜に水素が含まれることがある。水素が多量に侵入すると、 水素脆化が起こり皮膜の機械的性質が劣化するので、水素侵入をで きるだけ抑制しためっき処理法の開発が望まれている。

そこで本研究では、パラジウムめっき処理を行い,めつき皮膜中 の水素の固溶状態を調べた。めつき条件として、特に電流密度とめ っき時間を変化させてめつき処理を行い、得られためつき試料での 水素分析を行った。水素分析には昇温脱離法を用いた。まためっき 皮膜には転位などの各種の格子久陥が含まれ機械的性質に大きな影 響を及ぼすと推測されるので、各めっき試料を種々の熱処理温度で 熱処理して、水素の固溶状態の変化を調べた。

\section{2. 実験方法}

下地には板巢 $0.5 \mathrm{~mm}$ の市販銅板を用いて $25 \times 40 \mathrm{~mm}$ の形状 に切断し、前処理を行わずめつき処理を行った。Pd めつき浴に

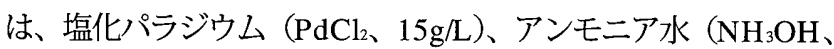
$40 \mathrm{~mL}$ )、蒸留水を加え $1 \mathrm{~L}$ とした塩化パラジウム浴を使用した。 本研究では、Pdめつきの特徴を明らかにするために、 $\mathrm{Cu}$ めつ き皮膜と Ni めつき皮膜での水素分析も行った。この際、 $\mathrm{Cu}$ めつ き浴には硫酸銅浴を用いた。また、Ni めつき浴にはワット浴を 用いた。

Pd めつきの際の対極には白金線を用いた。また、 $\mathrm{Cu}$ めっの 際には下地材料と同じ素材の $\mathrm{Cu}$ 板を、Ni めっきの際には市販の 純 Ni 板を、それぞれ対極として用いた。電流密度は 50 ～250 $\mathrm{A} / \mathrm{m} 2$ 、分極時間は $200 \sim 5000 \mathrm{~s}$ とした。めつき処理後、試料を 水道水で水洗し自然乾燥した後、水素分析を行った。

水素分析は昇温脱離法で行った。水素検出のための質量分析型真 空計、試料加熱のための赤外線ゴールドイメージ炬、炬内を真空排 気するための真空排気装置から構成される昇温脱離型水素分析装置 を自作して、水素分析に用いた。試料の加熱温度は室温〜 $800{ }^{\circ} \mathrm{C}$ とし、昇温速度は $0.67^{\circ} \mathrm{C} / \mathrm{s}$ とした。

$\mathrm{X}$ 線回折図形の測定には $\mathrm{Cu}$ 管球を用い、X 線回折図形の解 析には装置（フィリップス社製試料水平型 X 線回折装置）に付属
のソフトを用いた。

\section{3. 実験結果}

3. 1 めつき試料表面の観察

$\mathrm{Pd} 、 \mathrm{Cu} 、 \mathrm{Ni}$ めつき試料表面を目視観察した。Pd めつき試料 の場合には、光沢のない灰色を有し、金属 $\mathrm{Pd}$ の色調と似ており、 電析物は金属 Pd であると推測された。 $\mathrm{Cu}$ めっき試料の表面は 銅色を呈しており、電析物は金属銅であると推測された。Ni め つき試料の場合には光沢を有する銀白色を呈しており、金属 $\mathrm{Ni}$ であると推測された。

\section{2 めつき処理の際の電流効率}

Fig 1 は、Pd めつき処理に伴う試料質量の増加分と分極時間の 関係であり、試料質量の増加分は通電電気量にほぼ比例する。そこ で、電析物は金属状態であると仮定して、Fig.1 の直線の傾きか ら電析反応に関する電流効率を算出した。Fig.2 に示すように、Pd めつきの場合には、 $50 \mathrm{~A} / \mathrm{m}^{2}$ でほぼ 70\%であり、100A $/ \mathrm{m}^{2}$ になると ほぼ 100\%になるが、それよりも電流密度が大きくなると、電流 効率が減少する。一方、Cu めっきと Ni めっきの場合には、電流 密度に関わらずほぼ 100 \%の電流効率になる。

Fig.2 に示した電流効率の值からすれば、Pd めつき処理の場合 には、Pdの電析反応に加えて水素の発生反応も起こっているも のと推測される。一方、 $\mathrm{Cu}$ めっきと $\mathrm{Ni}$ めっ処理の場合には、 水素発生反応はあまり起こらないことになる。

\section{3 めつき試料の水素分析}

$\mathrm{Pd} 、 \mathrm{Cu} 、 \mathrm{Ni}$ めつき試料において、昇温脱離法で測定された水 素の昇温脱離スペクトルを Fig.3 に示す。3 種類のめっき試料の 昇温脱離スペクトルともに、水素の放出ピークが認められる。つま り、 $\mathrm{Pd} 、 \mathrm{Cu} 、 \mathrm{Ni}$ めっき試料には水素が含まれる。また、 $\mathrm{Pd} 、 \mathrm{Ni}$ めっき試料の場合にはいくつかの水素放出ピークが認められ、 $\mathrm{Cu}$ めつき試料の場合には 1 つの水素放出ピークのみである。

下地銅板をカソード分極し、水素の昇温脱離スペクトルを測定し ても水素放出ピークは認められないので、それら水素放出ピークは めつき皮膜に含まれる水素の放出に起因するものであることがわか る。これらの水素放出ピークは比較的高温にあり、試料を高温に加 熱しないと、その水素は放出されないことになる。

\section{4 熱処理に伴うPdめっき皮膜の構造変化}

いくつかの温度で熱処理した Pd めつき試料で測定された X 線 回折図形を Fig 4 に示す。熱処理に伴って回折ピークの位置や形 が僅かに変化している。また、高温で熱処理すると、Pdめっき 膜と下地銅板の間で合金相の形成が起こっているように見える。

このような X 線回折図形を解析して、Pdの格子定数、半価幅、 ピーク強度を求めた。Fig.5 に示すように、600 ${ }^{\circ} \mathrm{C}$ 以上で熱処理 
すると格子定数が変化する。また、室温から $300{ }^{\circ} \mathrm{C}$ で熱処理する

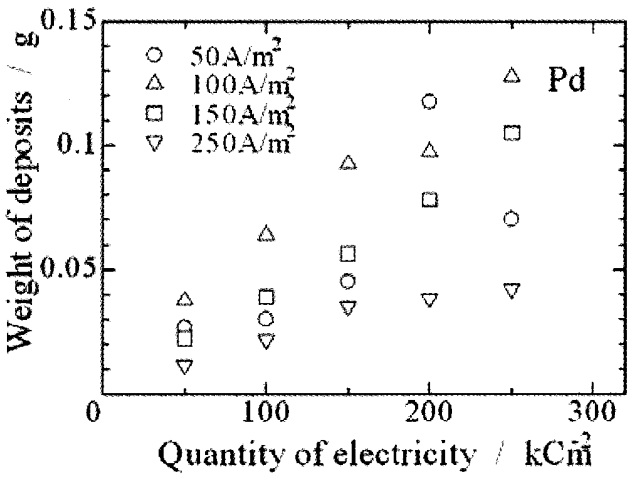

Fig.1 Relation between the weight of deposits calculated from the increase in specimen weight caused by electroplating and the quantity of electricity.

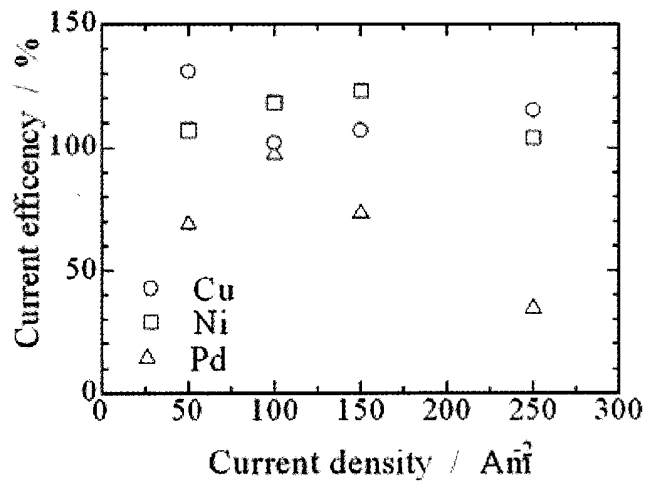

Fig 2 Current efficiency calculated from the slope of the lines shown in Fig.1.

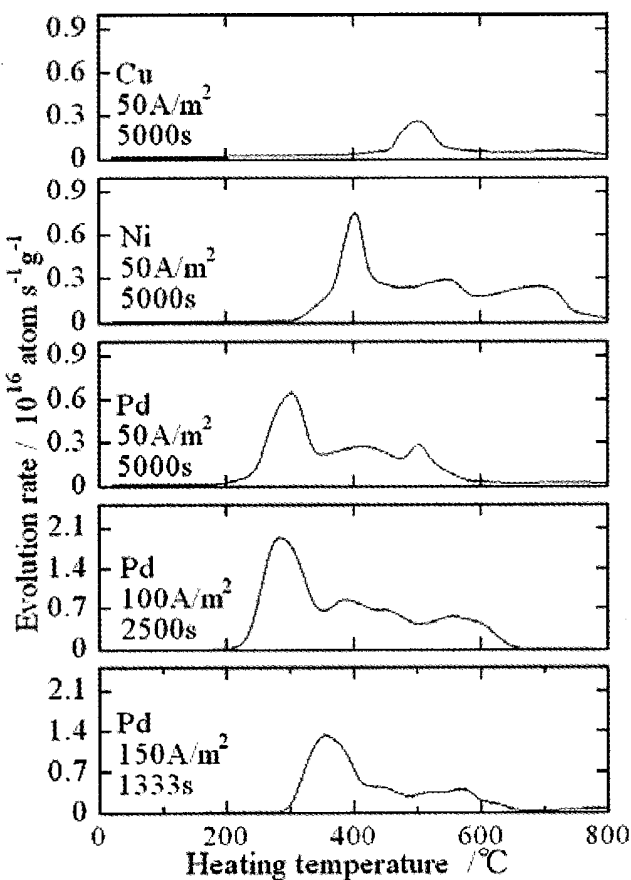

Fig.3 Thermal spectrum of hydrogen evolution rate measured for the specimens electroplated with $\mathrm{Cu}, \mathrm{Ni}$, and $\mathrm{Pd}$ at various current densities.
と半価幅が減少し、ピーク高さが大きくなる。

これらの変化と水素の昇温脱離スペクトルを対応させると、めつ き皮膜における塑性ひずみの消滅と水素放出か㳔応しているように 見える。

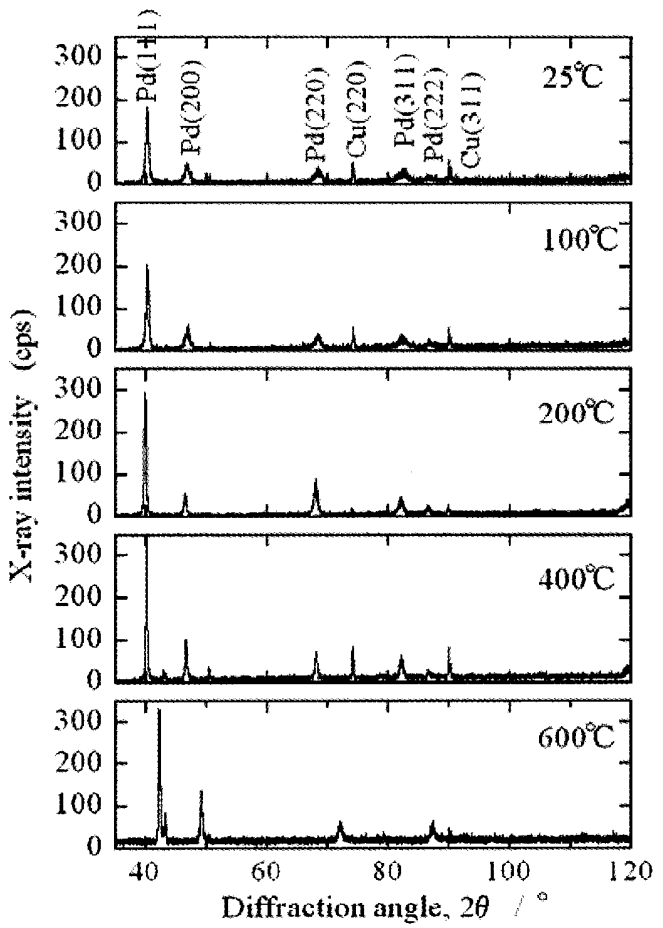

Fig.4 X-ray diffraction patterns obtained for the Pd-electroplated specimens which were heat-treated at various temperatures.
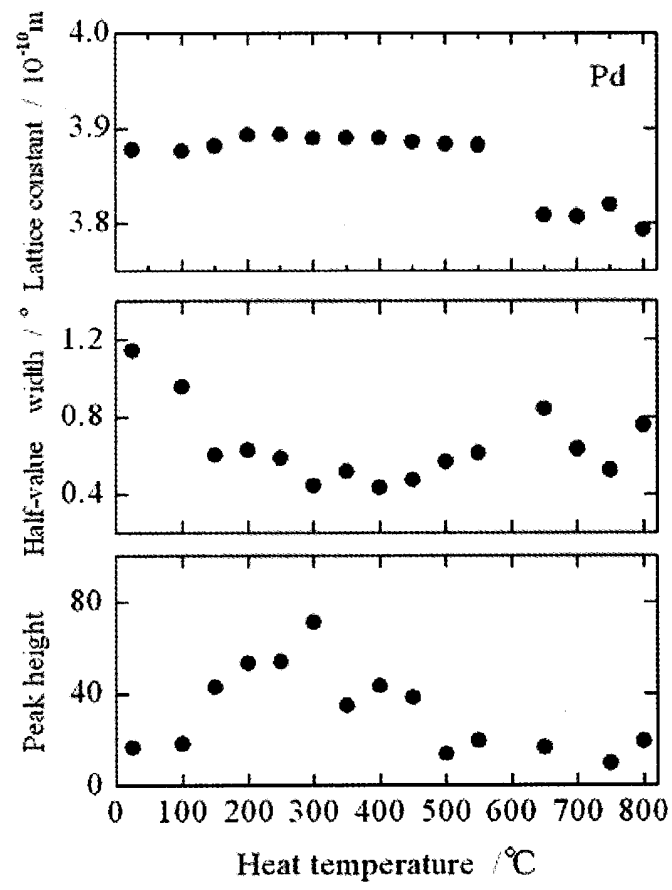

Fig 5 Lattice constant, half-value width, and peak height of the X-ray diffraction peak of Pd obtained for the Pd-electroplated specimens which were heat-treated at various temperatures. 